\title{
Polycyclic Aromatic Hydrocarbon and Metal Concentrations in Imported Canned Maize
}

\author{
Embbey K. Ossai ${ }^{1}$, Chukwujindu M.A. Iwegbue ${ }^{1 \& 2^{*}}$, Elizabeth E. Ajogungbe ${ }^{1}$, Godswill O. Tesi ${ }^{1}$ \\ ${ }^{1}$ Metals and Trace Organic Research Group, Department of Chemistry, Delta State University, P.M.B 1 Abraka, Delta State, Nigeria \\ ${ }^{2 *}$ School of Chemistry and Physics, University of KwaZulu-Natal, Private Bag X54001, Durban 4000, South Africa.
}

\section{A R T I C L E I N F O}

\section{Article history:}

Received 22 May 2014

Accepted 30 June 2014

Available online, ISSN: 2148-127X

Keywords:

Polycyclic aromatic hydrocarbons

Metals

Canned food

Nigeria

${ }^{*}$ Corresponding Author:

E-mail: maxipriestley@yahoo.com

\section{A B S T R A C T}

Concentrations and profile of polycyclic aromatic hydrocarbons(PAHs) and metals $(\mathrm{Cd}$, $\mathrm{Pb}, \mathrm{Ni}, \mathrm{Cr}, \mathrm{Fe}$ and $\mathrm{Mn}$ ) were determined in selected brands of canned maize in the Nigeria market with a view to providing information on the hazards associated with the consumption of these products. The measurement of the concentrations of PAHs was carried out by using a gas chromatography equipped with flame ionization detector (GCFID) after extraction by ultra-sonication with acetone/dichloromethane and clean-up. The 16 PAH concentrations varied between 45.1 and $335.7 \mu \mathrm{g} / \mathrm{kg}$. The concentrations of the indicators for occurrence and effects of PAHs in food varied from 3.6 to $114.5 \mu \mathrm{g} / \mathrm{kg}$ for $\mathrm{BaP}, 6.4$ to $168.2 \mu \mathrm{g} / \mathrm{kg}$ for PAH2, 11.8 to $232.7 \mu \mathrm{g} / \mathrm{kg}$ for PAH4 and 19.4 to 327.3 $\mu \mathrm{g} / \mathrm{kg}$ for PAH8. The concentrations of metals were determined by using atomic absorption spectrometry after acid digestion. The concentrations of metals in these samples ranged from $<0.05$ to $0.9 \mu \mathrm{g} / \mathrm{g}$ for $\mathrm{Cd}$; 5.0 to $8.0 \mu \mathrm{g} / \mathrm{g}$ for $\mathrm{Pb}, 0.8$ to $1.7 \mu \mathrm{g} / \mathrm{g}$ for $\mathrm{Fe}$ while $\mathrm{Cr}$ and $\mathrm{Mn}$ were less than the limits of quantification $(<0.05 \mu \mathrm{g} / \mathrm{g})$. The concentrations of $\mathrm{Cd}$ and $\mathrm{Pb}$ in these canned maize samples were above their permissible limits for foods.

\section{Introduction}

Polycyclic aromatic hydrocarbons (PAHs) are a diversified group of over 100 organic compounds with two or more aromatic and/pentacyclic rings in a linear, angular or cluster formation (Tuteja et al., 2011; Martorell et al., 2011), and a number of which have proven carcinogenic, mutagenic and genetoxic properties. PAHs are ubiquitous environmental contaminants which are mainly produced from the incomplete combustion or pyrolysis of organic materials and natural combustion such as volcanic eruptions and forest fires. Other anthropogenic sources include emissions from the industries, waste incineration, road traffic and heating system (Naccari et al., 2011). PAHs have relatively low water solubility but are highly lipophilic, low biodegradability and are capable of undergoing longrange atmospheric transportation and deposition. Because of these characteristics, PAHs are likely to cause adverse human health or environmental effects near to and distance from their source (Protocol on Persistent Organic Pollutant, 1999; Naccari et al., 2011).

PAHs occur in foodstuffs as a consequence of environmental contamination and the thermal processes to which the foods are subjected to during processing and manufacturing. Food processing methods such as drying, boiling, cooking, frying, grilling, roasting and smoking are recognised sources of PAHs in foods (Naccari et al., 2011; Marteroll et al., 2010; Ciecierska and Obiedzinski, 2007).

The United States Environmental Protection Agency (USEPA) and European Union have identified the following 16 most frequently occurring/or dangerous PAHs as priority pollutants that needed to be monitored in environmental matrices. They include naphthalene (Nap), acenaphthylene (Acy), acenaphthene (Ace), fluorene (Flu), phenanthrene (Phe), anthracene (Ant), fluoranthene (Flt), pyrene (Pyr), benzo(a)anthracene (BaA), chrysene (Chy), benzo(b)fluoranthene $(\mathrm{BbF})$, benzo(k)fluoranthene $(\mathrm{BkF})$, benzo(a)pyrene (BaP), indeno(1,2,3-cd)perylene (IndP), dibenzo(a,h)anthracene (DahA) and benzo(ghi)perylene (BghiP). The International Agency for Research on Cancer (IARC) has further classified benzo(a)pyrene as group 1A (carcinogenic to humans), dibenzo(a,h)anthracene group 2A (probably carcinogenic to humans) and benzo(a)anthracene, benzo(b)fluoranthene, benzo(k)fluoranthene, chrysene and indeno(1,2,3-cd)perylene as group 2B (possibly 
carcinogenic to human), while other are not classifiable as their carcinogenicity to humans (IARC, 2010).

Metal ions play significant roles in human health and diseases which ranged from the dietary requirement of essential trace elements and toxicity associated with the overload of essential and toxic metals (Hague et al. 2008). These reasons have prompted research in the determination of metal concentrations in food items. Some metals such as $\mathrm{Hg}, \mathrm{Cd}$, and $\mathrm{Pb}$ cannot be tolerated even at low levels because they are exceptionally toxic to humans (Suppin et al., 2006). For example, cadmium accumulates in human body and may induce kidney dysfunction, skeletal damage, hypertension, tremor and hepatic and reproductive deficiencies. Also, Cadmium is a cell poison that causes different types of damages, including cell death or an increase in cell proliferation. For this reason, the International Agency for Research in Cancer (IARC) has categorized $\mathrm{Cd}$ as a group $2 \mathrm{~A}$ carcinogen (FDA, 2001). Lead absorption may constitute a serious risk to public health. Lead can inhibit cognitive development and intellectual performance in children, and increased blood pressure and cardiovascular disease in adult (Suppin et al. 2006). Exposure to lead has been associated with slow growth, hyperactivity, antisocial behaviours and impaired learning and hearing (Dahiya et al. 2005). On the other hand, chromium, cobalt, copper, iron, zinc and manganese are essential for human health. However, for metal micronutrients, there are fixed allowed levels for adequate dietary intake. At high concentrations, chromium, zinc cause nephritis anuria and extension of lesions in the kidney (Iwegbue et al. 2009; Iwegbue et al. 2010). In addition to the endogenous metal ion content of foodstuffs, numerous steps during processing and packing may add to the metal load. This is exemplified by authorised used of many metal containing additives such as the 'anti-oxidant' stannous chloride (Hague et al. 2008).

Canning makes food available for consumption far away from production sites. Trans-boundary movement of food products requires proper scrutiny. Thus constant monitoring of food products is needed to ensure the levels of these contaminants does not exceed their stipulated maximum limits. A survey of literature reveals that limited information are currently available on the concentrations and profiles of PAHs and heavy metals in the different brands of canned maize available in the Nigerian market. The objective of this study was to determine the concentrations of PAHs and metals in canned maize commonly consumed in Nigeria.

\section{Materials and Methods}

\section{Reagents}

All chemicals and reagents used were of analytical grade. Dichloromethane (LC grade), Acetone (Rieldel-de Haën, Seelze, Germany, purity 99.8\%), anhydrous sodium sulfate (purity 99\%), silica gel was obtained from BDH (Poole, UK). A PAH standard mixture containing the 16 priority PAHs, namely naphthalene (Nap) $1000 \mu \mathrm{g} / \mathrm{mL}$, acenaphthylene (Acy) $2000 \mu \mathrm{g} / \mathrm{mL}$, acenaphthene (Ace) (1000 $\mu \mathrm{g} / \mathrm{mL})$, fluorene (Flu) (199.9 $\mu \mathrm{g} / \mathrm{mL})$, phenanthrene (Phe) $99.8 \mu \mathrm{g} / \mathrm{mL}$, anthracene (Ant) (100.0 $\mu \mathrm{g} / \mathrm{mL})$, fluoranthene (Flt) $200.1(\mu \mathrm{g} / \mathrm{mL})$, pyrene (Pyr)
$99.9 \mu \mathrm{g} / \mathrm{mL}$, benzo(a)anthracene ( BaA) $(100.1 \mu \mathrm{g} / \mathrm{mL})$, chrysene (Chy) (100.0 $\mu \mathrm{g} / \mathrm{mL})$, benzo(b)fluoranthene (BbF) $(200.2 \mu \mathrm{g} / \mathrm{mL})$, benzo(k)fluoranthene $(\mathrm{BkF})(99.9$ $\mu \mathrm{g} / \mathrm{mL})$, benzo(a)pyrene (BaP) $(100.0 \mu \mathrm{g} / \mathrm{mL})$, dibenzo(a,h) anthracene (DahA) $200.0 \mu \mathrm{g} / \mathrm{mL}$, indeno(1,2,3-cd)perylene (IndP) $100.1 \mu \mathrm{g} / \mathrm{mL}$ and benzo(g,h,i)perylene (BghiP) was purchased from Supelco (Bellefonte, PA, USA). Working mixed standard solutions containing all the PAHs were prepared by the dilution of the stock solution with acetone and store at $20^{\circ} \mathrm{C}$ in darkness to avoid volatilization and photo degradation. Nitric acid, perchloric acid and sulphuric acids were obtained from BDH (Poole, United Kingdom). Working standards of the metals $(\mathrm{Cd}, \mathrm{Pb}, \mathrm{Ni}, \mathrm{Cr}, \mathrm{Fe}$ and $\mathrm{Mn}$ ) were prepared by diluting concentrated stock solution (Merck, Darmstadt, Germany) of $1000 \mathrm{mg} \mathrm{L}^{-1}$ with $0.25 \mathrm{~mol} \mathrm{~L}^{-1}$ nitric acid.

Sampling

A total of 5 brands of canned maize were collected from retail operation in Warri and Benin City, Nigeria. The choice of the samples was carefully made to reflect various brands consumed by the different income classes. Within a brand five to seven samples were collected and mixed together. From this a sub sample was obtained for PAHs analyses.

\section{Sample preparation, extraction and clean-up}

A mass of $10 \mathrm{~g}$ of the canned maize sample was weighed into a beaker and extracted with $50 \mathrm{~mL}$ of acetone and dichloromethane (DCM) in a ratio of $1: 1$ by ultra-sonication at $35^{\circ} \mathrm{C}$ for 30 minutes. The process was repeated times on the residue in fresh mixture of DCM/Acetone each time. The solvent extracts were combined and passed through a column packed with anhydrous sodium sulphate by using $50 \mathrm{~mL}$ of a $1: 1$ mixture of DCM/acetone. The eluted fractions were transferred into a rotary evaporator to evaporate the volume to $2 \mathrm{~mL}$. The extracts were subjected to purification by using solid phase with activated silica gel and eluted with $20 \mathrm{~mL}$ of dichloromethane (DCM). The extracts were collected and concentrated to $2 \mathrm{~mL}$ by using a rotary evaporator. The concentrated extract was transferred into a vial bottle using a pipette and store at $4^{\circ} \mathrm{C}$ before analysis.

\section{Chemical Analysis}

Samples were analysed for 16 PAHs by a gas chromatography (Hewlett Packard 6890) equipped with a HP5 capillary column (Cross linked PHME Siloxane) $(0.25 \mu \mathrm{m}$ film thickness $\times 0.25 \mu \mathrm{m} \times 30 \mathrm{~m})$ and Flame ionization detector (FID). A $0.5 \mu \mathrm{L}$ aliquot of the extract was manually injected with a syringe. The injector temperature was $250^{\circ} \mathrm{C}$. The temperature program was initially set at $60^{\circ} \mathrm{C}$, held at $60^{\circ} \mathrm{C}$ for $1 \mathrm{~min}$ followed by a $20^{\circ} \mathrm{C} / \mathrm{min}$ ramping to a final temperature of $300^{\circ} \mathrm{C}$. Helium was used as a carrier gas at a flow rate of 1.36 $\mathrm{mL} / \mathrm{min}$. Quantification was carried out by external standard method.

\section{Metal Analysis}

A mass of $1 \mathrm{~g}$ of the sample was weighed into a beaker and $20 \mathrm{~mL}$ of the acid mixture (perchloric acid, nitric acid and sulphuric acid in the ratio of $1: 2: 2$ ) was 
added to the beaker containing the sample. Thereafter, the sample was placed in the fume cupboard and heat to $120^{\circ} \mathrm{C}$ for $1 \mathrm{~h}$ on regulated hotplate until white fumes were observed. After which the sample was allowed to cool and filtered by using a Whatman No. 42 filter paper, and made to $25 \mathrm{~mL}$ with ultra-pure water. The samples were analysed for metal contents by using atomic absorption spectrophotometry (Perkin Elmer Analyst 200, USA).

\section{Quality Control/Assurance}

To evaluate the extraction efficiency for the PAH compounds, recovery studies were carried out by spiking selected already analysed samples with known standards of the individual PAH compounds and re-analysing the samples. The recoveries for the PAH compounds, $r^{2}$ values for the calibration lines for the PAH compounds, limits of detection and quantification are displayed in Table 1 while the recoveries for metals for analysis of certified reference material DORM-2 are displayed in Table 2.

\section{Results and Discussion}

\section{Polycyclic Aromatic hydrocarbons}

The concentrations of PAHs in these brands of canned maize are showed in Table 3 while Figure 1 depicts the $\mathrm{PAH}$ profiles in the canned maize. The concentration and profile of PAHs in these brands of canned maize ranged between 45.1 and $441.3 \mu \mathrm{g} / \mathrm{kg}$. The highest concentration of the 16 PAH was observed in M-5. The concentrations and profile of PAHs varied significantly among the different brands of canned maize. In these brands naphthalene was not detected in any of the brands.
In these samples, naphthalene was below the limit of quantification. The three-ring PAHs (Acy +Ace+ Flu+ Phe+ Ant) varied from 12.7 to $114 \mu \mathrm{g} / \mathrm{kg}$, which constituted $7.8 \%$ to $57.2 \%$ of the 16 PAHs content. Phenanthrene and anthracene were not detected in these brands of canned maize. Acenaphthylene is the dominant three-ring PAHs in these brands of canned maize and was detected at concentrations of 6.4 to $54.8 \mu \mathrm{g} / \mathrm{kg}$. The highest acenaphthylene and Acenaphthene was detected in M-5. Acenaphthylene constituted $3.9 \%$ to $51.4 \%$ of the $\sum 16$ PAHs. Acenaphthylene was detected in 4 out of the 5 brands examined at concentrations varying from $6 \mu \mathrm{g} / \mathrm{kg}$ to $59.2 \mu \mathrm{g} / \mathrm{kg}$, which constituted $3.9 \%$ to $13.4 \%$ of the 16 PAHs contents of these brands of canned maize. Flourene was detected in M-1 and M-2 at concentrations of 2.6 $\mu \mathrm{g} / \mathrm{kg}$ which constituted $3.5 \%$ and $5.8 \%$ of the $\sum 16 \mathrm{PAHs}$ in brands M-1 and M-2 respectively.

The four-ring PAHs (Flt+Pyr+BaA+Chy) concentration ranged from 4.1 to $127.1 \mu \mathrm{g} / \mathrm{kg}$. The highest concentration of four-ringed PAHs were observed in brand M-5. The four-ringed PAHs constituted 5.5\% to $28.8 \%$ of the 16 PAHs in these brands of canned maize. Benzo(a)anthracene was detected in three samples at concentrations of 5.4 to $83.6 \mu \mathrm{g} / \mathrm{kg}$. In these 3 samples (M-1, M-2 and M-5), BaA constituted $3.5 \%$ to $18.9 \%$ of the $\sum 16$ PAHs. Chyresene is the dominant four-ringed PAH compound in these samples of canned maize in terms of concentration and frequency of occurrence. Chrysene was detected at concentrations of 2.8 to 53.7 $\mu \mathrm{g} / \mathrm{kg}$ which constituted approximately $20 \%$ to $16 \%$ of the $\sum 16$ PAHs.

Table 1 Percent recoveries, correlation coefficients for calibration lines, limits of detection (LOD) and limits of quantification (LOQ) for each of the 16 PAH standards.

\begin{tabular}{|c|c|c|c|c|}
\hline $\mathrm{PAH}$ & Percent Recovery (\%) & $\mathrm{R}^{2}$ & $\operatorname{LOD}\left(\mu \mathrm{g} \mathrm{kg}^{-1}\right)$ & LOQ $\left(\mu \mathrm{g} \mathrm{kg}^{-1}\right)$ \\
\hline Acenaphthene & 97.2 & 0.9999 & 0.02 & 0.2 \\
\hline Acenaphthylene & 93.4 & 0.9993 & 0.02 & 0.2 \\
\hline Anthracene & 78.5 & 0.9996 & 0.02 & 0.2 \\
\hline Benzo(a)anthracene & 77.6 & 0.9995 & 0.04 & 0.4 \\
\hline Benzo(a)pyrene & 98.7 & 0.9993 & 0.02 & 0.2 \\
\hline Benzo(b)anthracene & 90.6 & 0.9993 & 0.03 & 0.3 \\
\hline Benzo(g,h,i)perylene & 98.4 & 0.9996 & 0.03 & 0.3 \\
\hline Benzo(k)fluoranthene & 93.2 & 0.9991 & 0.02 & 0.2 \\
\hline Chrysene & 92.4 & 0.9996 & 0.01 & 0.1 \\
\hline Dibenzo(a,h)anthracene & 93.4 & 0.9994 & 0.03 & 0.3 \\
\hline Fluoranthene & 93.6 & 0.9995 & 0.02 & 0.2 \\
\hline Fluorene & 87.6 & 0.9998 & 0.06 & 0.6 \\
\hline Indeno(1,2,3-cd)perylene & 87.6 & 0.9998 & 0.07 & 0.7 \\
\hline Naphthalene & 69.6 & 0.9995 & 0.01 & 0.1 \\
\hline Phenathrene & 79.7 & 0.9998 & 0.01 & 0.1 \\
\hline Pyrene & 83.3 & 0.9999 & 0.01 & 0.1 \\
\hline
\end{tabular}

Table 2 Validation Method with Standard Reference Material Dorm-2 (Dogfish Muscle) ( $\mu \mathrm{g} / \mathrm{g}$ dry weight)

\begin{tabular}{l|cc}
\hline Elements & Certified value & Measured value \\
\hline $\mathrm{Cd}$ & $0.043 \pm 0.08$ & $0.042 \pm 0.04$ \\
$\mathrm{~Pb}$ & $0.065 \pm 0.007$ & $0.059 \pm 0.06$ \\
$\mathrm{Ni}$ & $19.45 \pm 3.1$ & $17.7 \pm 3.6$ \\
$\mathrm{Cr}$ & $34.7 \pm 5.5$ & $31.9 \pm 4.8$ \\
$\mathrm{Fe}$ & $142 \pm 10$ & $126.4 \pm 8.2$ \\
$\mathrm{Mn}$ & $3.66 \pm 0.34$ & $3.55 \pm 0.28$ \\
\hline
\end{tabular}


Table 3 Concentration of PAHs in $\mu \mathrm{g} / \mathrm{kg}$ in canned maize

\begin{tabular}{|c|c|c|c|c|c|}
\hline PAH COMPONENT & M-1 & M-2 & M-3 & M-4 & M-5 \\
\hline Naphthalene & $<0.1$ & $<0.1$ & $<0.1$ & $<0.1$ & $<0.1$ \\
\hline Acenaphthylene & 9.3 & 23.2 & 6.4 & 27.5 & 54.8 \\
\hline Acenaphthene & 6.0 & $<0.2$ & 6.3 & 41.0 & 59.2 \\
\hline Fluorene & 2.6 & 2.6 & $<0.6$ & $<0.6$ & $<0.6$ \\
\hline Phenanthrene & $<0.2$ & $<0.2$ & $<0.2$ & $<0.2$ & $<0.2$ \\
\hline Anthracene & $<0.2$ & $<0.2$ & $<0.2$ & $<0.2$ & $<0.2$ \\
\hline Fluoranthene & $<0.2$ & $<0.2$ & $<0.2$ & $<0.2$ & $<0.2$ \\
\hline Pyrene & $<0.1$ & $<0.1$ & $<0.1$ & $<0.1$ & $<0.1$ \\
\hline Benzo(a)anthracene & 5.4 & $<0.4$ & 5.7 & $<0.4$ & 83.6 \\
\hline Chrysene & 2.8 & 4.1 & 3.2 & 53.7 & 43.5 \\
\hline Benzo(b)fluoranthrene & $<0.3$ & 5.0 & $<0.3$ & 26.4 & 25.3 \\
\hline Benzo(k)fluoranthrene & 42.2 & $<0.2$ & 75.2 & 30.7 & 69.9 \\
\hline Benzo(a)pyrene & 3.6 & 10.2 & 65.8 & 114.5 & 80.3 \\
\hline Indeno(1,2,3-cd)perylene & 2.7 & $<0.7$ & $<0.7$ & 42.0 & 24.7 \\
\hline Dibenzo(a,h)anthracene & $<0.3$ & $<0.3$ & $<0.3$ & $<0.3$ & $<0.3$ \\
\hline Benzo(g,h,i)perylene & $<0.3$ & $<0.3$ & $<0.3$ & $<0.3$ & $<0.3$ \\
\hline TOTAL & 74.6 & 45.1 & 162.6 & 335.7 & 441.3 \\
\hline 2-ring & - & - & - & - & - \\
\hline 3-ring & 17.9 & 25.8 & 12.7 & 68.5 & 114 \\
\hline 4-ring & 8.2 & 4.1 & 8.9 & 53.7 & 127.1 \\
\hline 5-ring & 45.8 & 15.2 & 141 & 171.6 & 175.5 \\
\hline 6-ring & 2.7 & - & - & 42 & 24.7 \\
\hline PAH2 & 6.4 & 14.3 & 69 & 168.2 & 123.8 \\
\hline PAH4 & 11.8 & 19.3 & 74.7 & 194.6 & 232.7 \\
\hline PAH8 & 56.7 & 19.3 & 149.9 & 267.3 & 327.3 \\
\hline
\end{tabular}

PAH2 (Chry + BaP); PAH4 (PAH2 + Bbf + BaA); PAH8 (PAH4 + BkF + IndP + DahA + BghiP)

Table 4 Concentrations of metals $(\mu \mathrm{g} / \mathrm{g})$ in canned maize samples

\begin{tabular}{l|lllll}
\hline METALS & M-1 & M-2 & M-3 & M-4 & M-5 \\
\hline $\mathrm{Cd}$ & 0.7 & $<0.05$ & $<0.05$ & $<0.05$ & 0.9 \\
$\mathrm{~Pb}$ & 6.0 & 8.0 & 8.0 & 5.0 & 5.0 \\
$\mathrm{Ni}$ & 1.4 & 0.8 & 1.7 & 1.1 & 1.0 \\
$\mathrm{Cr}$ & $<0.05$ & $<0.05$ & $<0.05$ & $<0.05$ & $<0.05$ \\
$\mathrm{Fe}$ & 163.4 & 193.6 & 181.7 & 92.4 & 114.1 \\
$\mathrm{Mn}$ & $<0.05$ & $<0.05$ & $<0.05$ & $<0.05$ & $<0.05$ \\
\hline
\end{tabular}

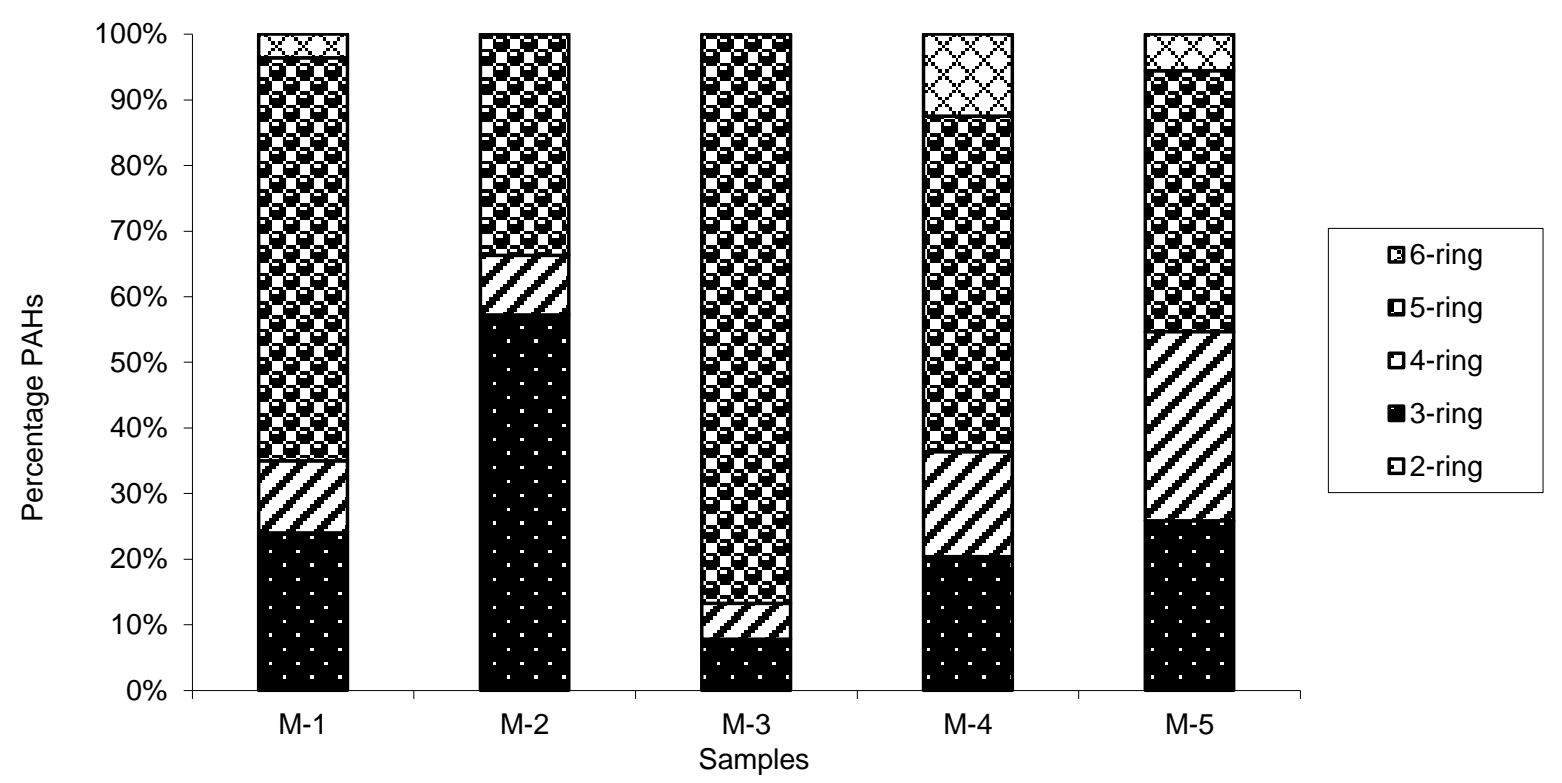

Figure 1 PAHs profiles in canned maize samples 
The concentration of five-ring PAHs $(\mathrm{Bbf}+\mathrm{Bkf}+\mathrm{BaP}$ + DahA) ranged from 15.2 to $175.5 \mu \mathrm{g} / \mathrm{kg}$ which constituted $33.7 \%$ to $86.7 \%$ of the 16 PAHs in these brands of canned maize. The five-ring PAHs are the most abundant $\mathrm{PAH}$ compounds in these brands of canned compared with 2, 3, 4 and 6-ring PAHs. Benzo(a)pyrene was the dominant five-ring $\mathrm{PAH}$ compound in these canned maize and occurred at concentrations of $3.6 \mu \mathrm{g} / \mathrm{kg}$ to $114.5 \mu \mathrm{g} / \mathrm{kg}$. The concentrations of $\mathrm{BaP}$ in these products were above the permissible limit of $\mathrm{BaP}$ in cereal products. BaP constituted $4.8 \%$ to $40.5 \%$ of the $\sum 16$ PAHs content. The concentrations of benzo(b)fluoranthrene and benzo(k)fluranthrene were 5 $\mu \mathrm{g} / \mathrm{kg}$ to $26.4 \mu \mathrm{g} / \mathrm{kg}$ in three of the brands respectively. Benzo(b) fluoranthrene and benzo(b)fluoranthrene constituted 5.75 to $11.1 \%$ and $9.2 \%$ to $56.5 \%$ of the $\sum 16$ PAHs in these brands of canned maize.

Indeno(1,2-3 cd)perylene was the only six-ringed PAHs compound found in these products. Indeno(1,2-3 cd) perylene was found in M-1, M-5 and M-6 at concentrations of $2.7,42.0$ and $24.7 \mu \mathrm{g} / \mathrm{kg}$ respectively. In these samples, IndP constituted 3.6 to $12.5 \%$ of the $\sum 16$ PAHs.

In 2008, European Food Safety Authority (EFSA) established that the following PAHs: BaA, Chy, BbF, $\mathrm{BbF}, \mathrm{BkF}, \mathrm{BaP}$, IndP, DahA and BghiP have known oral carcinogenity and suggested that these PAHs (PAH8) or the subgroup of $\mathrm{PAH} 4(\mathrm{Chy}+\mathrm{BaA}+\mathrm{BbF}+\mathrm{BaP})$ or the subgroup of $\mathrm{PAH} 2$ (Chy+ $\mathrm{BaP}$ ) are the best indicators for the occurrence and effects of PAHs in food rather than the use of $\mathrm{BaP}$ alone as indicator. The concentrations of PAH2, PAH4 and PAH8 in these brands of canned maize ranged from 6.4 to $168.2 \mu \mathrm{g} / \mathrm{kg}, 11.8-232.7 \mu \mathrm{g} / \mathrm{kg}$ and 19.3 to $367.3 \mu \mathrm{g} / \mathrm{kg}$ respectively. The highest concentrations of PAH4, PAH8 were found in brand M-5 while M-2 had the highest concentration of PAH2. In this study, PAH2, PAH4 and PAH8 constituted 8.6-50.1\%, $15.8-58.0 \%, 42.8$ to $92.2 \%$ of the 16 PAHs respectively.

\section{Metals contents in canned maize}

The concentrations of metals showed significant interbrand variations $(\mathrm{P}<0.05)$. The concentrations of $\mathrm{Cd}$ in samples ranged from $<0.05$ to $0.9 \mu \mathrm{g} / \mathrm{g}$ (Table 4). The concentration of $\mathrm{Cd}$ in brands M-1 and M-5 were above the $0.5 \mu \mathrm{g} / \mathrm{g}$ Codex Committee on Food Additives and Contaminants (CCFAC, 2001) permissible limit of $\mathrm{Cd}$ in food.

The concentrations of $\mathrm{Pb}$ in these samples of canned maize ranged between 5.0 and $8.0 \mu \mathrm{g} / \mathrm{g}$. The highest concentrations were observed in brand $\mathrm{M}-2$ and $\mathrm{M}-3$. The permissible level of $\mathrm{Pb}$ in canned food is $1 \mu \mathrm{g} / \mathrm{g}$. The concentrations of $\mathrm{Pb}$ in these brands of canned were 5 to 8 times above the permissible limit. The major source of $\mathrm{Pb}$ in canned food is leaching from the soldering of the can and in addition to the background $\mathrm{Pb}$ content of the maize. The concentrations of $\mathrm{Ni}$ in these samples of canned maize ranged from $0.8 \mu \mathrm{g} / \mathrm{g}$ in brand $\mathrm{M}-2$ to 1.7 $\mu \mathrm{g} / \mathrm{g}$ in brand $\mathrm{M}-3$. There is no specific guideline for $\mathrm{Ni}$ in food in Nigeria. However, excessive intake of Ni could lead to contact dermatitis in pre-sensitized individuals. Chromium and manganese in the food were below detection limit and therefore does not pose any health risk to the consumer. However, $\mathrm{Fe}$ was detected at concentrations that varied between $92.48 \mu \mathrm{g} / \mathrm{g}$ and 193.6 $\mu \mathrm{g} / \mathrm{g}$. The highest Fe concentration was observed in $\mathrm{M}-2$. Exposure to excess $\mathrm{Fe}$ can lead to numerous pathological events (Ponka et al., 2007; Mol, 2011). A maximum limit of $15 \mu \mathrm{g} / \mathrm{g} \mathrm{Fe}$ in canned foods was recommended (Anonymous, 2002). In this study, the canned maize samples had Fe concentrations above the recommended levels of $\mathrm{Fe}$ in canned foods.

\section{Conclusion}

The concentrations of $\mathrm{Cd}, \mathrm{Pb}$ and $\mathrm{Fe}$ in these samples of canned maize were above permissible limits allowed in canned food while metals such as $\mathrm{Mn}$ and $\mathrm{Cr}$ were below the limits of detection. The concentration and Profile of PAHs indicated that these samples of canned maize contained high levels of the suggested indicators for occurrence and effects of PAHs in foods such as BaP, PAH2, PAH4 and PAH8 far above permissible limits. Excessive consumption of these brands of canned maize could constitute serious health problem. The study demonstrates the urgent need for screening of transboundary food items for possible implementation risk management action. It also demonstrates the need to establish guidelines and standards for metals in canned foods products in Nigeria.

\section{References}

Anonymous. 2002. Gida Maddelerine Belirli Bulasanlarin Seviyelerinin Belirlennesi Hakkinda Teblig T.C. tarim ve Koyisleri Bakanligi Koruma ve Kontrol Genel mudurlugu Tebig No. 2002/63. Official paper No. 20.09.2002-24885.

CCFAC. 2001. Codex Committee on Food Additives and Contaminants, Comments submitted on draft maximum levels of lead and cadmium. Joint FAO/WHO food standards programme, thirty-third session. The Hague, the Netherlands 12-16 March 2001.

Ciecierska M, Obiedzinski M. 2007. Canned fish products contamination by polycyclic aromatic hydrocarbons. Acta Sci Polon Technol. Aliment 6:19-28.

Codex Alimentarius Commission (CX/FAC06/38/36). 2005. Joint FAO/WHO food standards programme codex committee on food additives and contaminants. Discussion paper on polycyclic aromatic hydrocarbons (PAHs) contamination.

Dahiya S, Karpe R, Hegde AG, Sharma RM. 2005. Lead, cadmium and nickel in chocolate and candies from suburban areas of Mumbai, India. J Food Comp Anal 18: 517-522.

European Commission (EC). 2001. European Commission Regulation 2375/2001 of Nov 29, 2001, amending Commission Regulation (EC) 466/2001 setting maximum levels for certain contaminants in foodstuffs. Off. J. Eur. Communities, 2001, L 321/1-5.

European Food Safety Authority (EFSA). 2008. Polycyclic aromatic hydrocarbons in food. Scientific opinion of the panel on contaminant in food chains (Adopted on 9 June, 2008). EFSA Journal 724: 1-114. Available from http://www.efsa.europa.eu/EFSA/efsa-local-

1178620753812-1211902034842.htm/, Accessed on 5 October, 2011.

Food and Drug Administration (FDA). 2001. Dietary reference intakes for vitamin A, vitamin $\mathrm{K}$, arsenic, boron, chromium, copper, iodine, iron, manganese, molybdenum, nickel, silicon, vanadium, and zinc. Report of the Panel on Micronutrients. National Academy Press, Washington, DC, Food and Drug Administration. Dietary supplements. Center for Food Safety and Applied Nutrition 
Hague T, Petroczi A, Adrews PLR, Barker J, Naughton DP. 2008. Determination of metal ion contents of beverages and estimation of target hazard quotients: a comparative study. Chem Central J Doi: 10.1186/1752-153x-2-13.

International Agency for Research on Cancer (IARC). 2010 Some non-heterocyclic polycyclic aromatic hydrocarbons and some related exposures. IARC Monograph on the Evaluation of Carcinogenic Risks to Human. Monograph Vol 92

Iwegbue CMA, Nwajei GE, Arimoro FO, Eguavoen O. 2009. Characteristic levels of heavy metals in canned sardines consumed in Nigeria. Environmentalist 29: 431-435 doi: 10.1007/S10669-009-9233-5.

Iwegbue CMA, Nwozo SO, Overah LC, Nwajei GE, 2010. Survey of trace element composition of commercial infant food formulas in the Nigerian market. Food Addit Contam Part B doi:10.1080/1944-0049.2010.497502.

Martorell T, Perello G, Marti-Cid R, Castell V, Llobet JM, Damingo JL. 2010. Polycyclic aromatic hydrocarbons (PAHs) in foods and estimated intake by the population of Catalonia, Spain: Temporal trend. Environ Inter 36: 432-434.

Mol S. 2011. Determination of trace metals in canned anchovies and canned rainbow trout. Food Chem Toxicol 49: 348-351 doi:10.1016/jfct.2010.
Nacarri C, Cristani M, Giofre F, Ferrante M, Siracusa L, Tombetta D. 2011. PAHs concentration in heat treated milk sample. Food Res Inter 44: 716-724 doi:10.1016/j.foodres. 2010.12.2009.

Ponka P, Tenebeins M Eaton JW. 2007. Iron. In: Nordberg, G.F., Fowler, B.A., Nordberg $\mathrm{M}$ and Friberg L.T. (Eds.). Handbook on the toxicology of metals, third edn. Academic Press pp. 577-598.

Protocol on Persistent Organic Pollutants. 1999. The 1998 Aahrus protocol to the 1979 convention on long-range transboundary air pollutant on persistent organic pollutants (POPs). Rev. Eur. Community International Law 8: 224230.

Suppin D, Zahlbruchker R, Krapfenbauer-Coemak CH, HassanHawer CH, Smulders FJM. 2005. Mercury, lead and cadmium content of fresh and canned fish collected from Austrian retail operations. Ernahrung/Nutrition 29(11): 456460.

Tuteja G, Rout C, Bishnoi NR. 2011. Quantification of polycyclic aromatic hydrocarbons in leafy and underground vegetable. A case study of around Panipat City, Haryana, India. J Environ Sci Technol 4: 611-620. 